Article

\title{
Revitalizing the Global Alliances for Sustainable Development: Analyzing the Viability of Sustainable Development Goal 17- A Multi-Actor Governance Approach
}

\author{
Elena Bulmer ${ }^{1, *(1)}$ and Cristina del Prado-Higuera ${ }^{2}(\mathbb{D}$ \\ 1 Department of Operations and Data Science, EAE Business School (Madrid Campus), 28002 Madrid, Spain \\ 2 Departamento de Ciencias Jurídicas y Sociales, Universidad Rey Juan Carlos, 28032 Madrid, Spain; \\ cristina.delprado@urjc.es \\ * Correspondence: elena_bulmer@campus.eae.es
}

Citation: Bulmer, E.; del PradoHiguera, C. Revitalizing the Global Alliances for Sustainable Development: Analyzing the Viability of Sustainable Development Goal 17-A Multi-Actor Governance Approach. Sustainability 2021, 13, 4247. https://doi.org/ $10.3390 /$ su13084247

Academic Editor: Dorota Kuchta

Received: 17 March 2021

Accepted: 8 April 2021

Published: 11 April 2021

Publisher's Note: MDPI stays neutral with regard to jurisdictional claims in published maps and institutional affiliations.

Copyright: (c) 2021 by the authors. Licensee MDPI, Basel, Switzerland. This article is an open access article distributed under the terms and conditions of the Creative Commons Attribution (CC BY) license (https:// creativecommons.org/licenses/by/ $4.0 /)$.

\begin{abstract}
The seventeenth Sustainable Development Goal of the United Nations, Partnerships for the Goals, aims to strengthen the means of the implementation and revitalize the global partnership for sustainable development. The successful implantation of the UN's seventeenth Sustainable Development Goal will aid the execution and achievement of the other sixteen goals. This article explores the importance and viability of Sustainable Development Goal 17, using a case study based in Valencia, Spain. The study presents an illustrative stakeholder situation, where we see that there are conflicting interests among conservationists, fishermen, municipality representatives, and others. Data collection was done using desk-based research and semi-structured interviews. The interview process was performed between October 2018 and October 2019. In total, 21 different stakeholders were interviewed. For the data analyses, a stakeholder register, Power-Interest Matrices, and a stakeholder map were used, and, to complement the latter, narratives were developed. The different analyses showed that most project stakeholders supported the project, while there was really only one stakeholder, the fishermen themselves, who were reticent about participating. However, it was shown over time that, by developing a common vision with them, the fishermen came on board the project and collaborated with the scientists. Stakeholder engagement analyses are especially useful in the application of Sustainable Development Goals at the project level. Although this case study is specifically applicable to a marine conservation context, it may be extrapolated and applied to any other Sustainable Development Goals' context.
\end{abstract}

Keywords: global alliances; stakeholder management; Sustainable Development Goals

\section{Introduction}

The seventeen Sustainable Development Goals (SDGs) were developed at the United Nations (UN) Development Summit at Rio de Janeiro (RIO +20) held in 2012. The main objective of this summit was to create global goals that would resolve global environmental, social, and economic challenges. According to the UN, the definition of Sustainable Development is (to satisfy) the needs of the present generation without compromising the ability of future generations to satisfy their own needs. This definition of the term "Sustainable Development" is included in the Bruntland report from 1987 that was developed by the World Commission on Environment and Development (WCED), with the aim of developing long-term solutions related to sustainable development and to pursue these goals in the 21st century. Among the topics covered were the role of the international economy, population and human resources, food security, species ecosystems, energy, industry, and proposed legal principles for environmental protection [1]. The new SDGs came into place in 2015. There were 17 goals and 169 targets, and they formed part of the adoption of a document titled Transforming our World: The 2030 Agenda for Sustainable Development [2]. 
The seventeen SDGs entail a set of global priorities that need to be endeavored via a multi-actor type of governance. Governance in this respect is defined as "the sum of the many ways individuals and institutions, public and private, manage their common affairs [3]. Often, traditional governance was associated with one set of actors; however, the situation is changing through the increasing participation of a range of different stakeholders, and therefore no one domain of governance is the preserve of only one actor [4-6]. "Traditional modes of state-based regulation have come to be seen as limited in their reach, effectiveness, authority, or legitimacy such that tacking complex global environmental problems" [4] (page 366) such as those included amongst the SDGs. This change from government to governance has been demonstrated by a shift distribution of power and resources in the global political economy, with an increasing protagonist role for example for non-state actors such as non-governmental organizations, the civil society, local governments, and businesses. There are examples of multi-actor arrangements that range from non-state actor initiatives to certification projects (i.e., for timber, mining, or sustainable tourism, just to name a few examples). The seventeenth SDG (SDG 17), "Partnerships for the Goals," whose aim is to, "strengthen the means of the implementation and revitalize the global partnership for sustainable development" is an example of a multi-actor type of governance [7]. The idea is that, through the development and execution of the different targets comprised within this Goal, and the creation of alliances between different stakeholders, the rest of the SDGs will be achieved. Furthermore, SDG 17 "recognizes multi-stakeholder partnerships as important vehicles for mobilizing and sharing knowledge, expertise, technologies, and financial resources to support the achievement of the sustainable development goals in all countries, particularly developing countries" [7]. In 2019, the 2030 Agenda Accelerator was developed by the UN Department of Economic and Social Affairs (UN DESA) and The Partnering Initiative in collaboration with several other partners to significantly help accelerate effective partnerships in support of the Sustainable Development Goals [8]. A systemic perspective is therefore necessary when developing laws to implement sustainability policies in an effective way. However, not only the regulatory authorities are needed to implement change, but the global effort needed extends to everyone, and thus the need for SDG 17.

This article will explore the importance and viability of SDG 17, Partnering for the Goals through the analysis of one marine conservation case study. More specifically, the applicability of SDG 17 will be analyzed to assess the viability of SDG 14, "Life Under Water." The aim of SDG 14 is to conserve and sustainably use the oceans, seas, and marine resources [9]. This SDG entails fourteen targets, amongst which is Target 14.2, "By 2020, sustainably manage and protect marine and coastal ecosystems to avoid significant adverse impacts, including by strengthening their resilience, and take action for their restoration in order to achieve healthy and productive oceans" [9]. Marine conservation is an example of an environmental challenge that permeates national boundaries. As national governments have not been able to respond to these large-scale environmental challenges, non-state actors are stepping forward to offer alternative experimental approaches and innovative solutions [4]. A multi-actor governance approach, which entails novel partnerships and networks, is therefore necessary, encompassing many different stakeholders.

Although multi-actor governance has been shown to be an alternative, it does entail different forms of governance in different spheres of authority, which might lead to potential conflicts or problems. This article will analyze the multi-actor governance approach suggested by SDG17 using an illustrative marine conservation project. More specifically, this study will try to answer the following research questions:

1. Is a multi-actor governance approach needed in managing marine conservation projects?

2. Is a multi-actor governance approach effective in managing marine conservation projects? Was it effective in handling and managing the Valencian marine turtle conservation project?

The marine case study analyzed for this research is a marine turtle bycatch project based in the Valencia Community, located along the Mediterranean coast on the east side 
of the Iberian Peninsula. Marine turtles are animal species that are threatened worldwide. At present, all seven species of marine turtle are classified as threatened species by the International Union for the Conservation of Nature (IUCN), one of the largest conservation organizations in the world and represented in almost every country. The IUCN strives to provide "public, private and non-governmental organisations with the knowledge and tools that enable human progress, economic development and nature conservation to take place together" [10].

The marine turtles are presently threatened by five main hazards which are all anthropogenic. Amongst these are the (i) impact of fishing, (ii) direct take, (iii) coastal development, (iv) pollution and pathogens, and (v) global warming. These elements not only affect sea turtles, but also many other marine fauna and flora. Unlike hazards affecting terrestrial habitats, marine threats are not geographically bound, as all marine environments connect to each other, and thereby all marine fauna and flora are affected equally by them on a global basis. A recent example of this is the problem with marine plastic debris. A plastic bottle may be thrown into the Mediterranean Sea and end up in Latin America. Malpractice in waste management in a specific geographic area may therefore affect marine turtles everywhere as marine turtles are similarly not geographically bound and are affected everywhere by this now global problem. Sea turtles are presently globally distributed and are often present in the Atlantic, Pacific, and Indian oceans, as well as in the Mediterranean Sea; therefore, the plastic problem is bound to affect them anywhere in some way or other.

\section{Research Methodology}

A case study approach was undertaken for the data collection using desk-based research and semi-structured interviews. The case study analyzed was a sea turtle conservation project based in the Valencian Community in Spain. The objective of this project was to reduce sea turtle bycatch off the Levante Coast.

This case study presents a very revealing stakeholder situation, where we see that there are conflicting interests among conservationists, fishermen, municipality representatives, and others. The stakeholders interviewed entailed the following:

- Project Holding organization: "Asociación Chelonia" is a Spanish conservation NGO based in Madrid that possesses over twenty years of experience in the world of marine conservation in the Iberian Peninsula. For this study, several of the organization's members were interviewed.

- Other NGOs: the other NGOs included in this analysis include "Xaloc," which is a marine conservation organization based in Valencia, and "CEMMA," a conservation organization based in Galicia.

- Funders: the project funders include the American Fish and Wildlife Service (FWS), and the Spanish "Fundación Biodiversidad"

- State government: The General Secretariat of Fishing has a mandate from the Environment Ministry to develop the European Union's fisheries policy.

- Local government: Represented by the technician from the Environmental Department of the Generalitat (regional government of the Valencian Community)

- Fishermen: Only the Gandía fishermen's association was interviewed.

- Civil society.

The interview process was performed between October 2018 and October 2019. In total, 21 different stakeholders were interviewed. Among the interviewees were public officials with environmental responsibilities, fishermen's associations, NGOs and university professors. The interviews were performed in Spanish, transcribed (i.e., in Spanish) and subsequently analyzed to enable the development narratives.

The 21 semi-structured interview questions related to (1) the context and professional background of the interviewee, (2) their knowledge of each of the case studies being analyzed, (3) their knowledge of project stakeholder analyses, (4) their perception of the marine species being conserved, and (5) their definitions of the terms power and interest, 
along with a small power-interest matrix exercise through which interviewees had to value the level of power and interest of the following stakeholder groups with respect to the project's mission. All interviews were transcribed in Spanish, and the narratives were developed in English.

The stakeholder analyses were based firstly on the development of a stakeholder register (Figure 1 in the Section 3), which encompassed:

- Stakeholder identification information

- Stakeholder classification information (i.e., main expectations regarding the project, whether stakeholders were internal/external to the project, and whether they were supporters, opponents, or neutral.

- Problems experienced by interviewed stakeholders.

- Solutions to identified problems.

Based on the information included in the stakeholder register, a stakeholder map [11] was developed. According to Callon [12,13], the definitions and role of stakeholder in a project cannot be separated from their relationships [14]. Therefore, the conception of a stakeholder mapping exercise to better understand the project stakeholder relationships proved more than essential. Based on the information gathered in the stakeholder register, a stakeholder map was conceived using the 2002 Bonke and Winch stakeholder mapping model [8]. In this framework (Figure 2 in the Section 3), the central asset is the project mission, and the identified stakeholders are positioned around it. Their position in the project is identified as being a proponent or opponent as well as the potential problems that may be experienced.

To complement these analyses, Power-Interest (PI) matrices were also developed to compile the PI matrix information collected in the different interviews. This tool enables the categorization of stakeholders according to their level of power and interest in the project. For the PI Matrix analyses, the stakeholders included in the PI matrices were grouped according to the stakeholder categories listed above.

The results from the stakeholder register, PI matrices, and stakeholder map were further analyzed via the development of narratives. Organizational narratives are temporal in nature and are defined as being "discursive constructions that provide a means for individual, social, and organizational sensemaking and sense giving" [15]. This sense of temporality is very adequate to this research for several different reasons: firstly, the nature of a project is temporal as a project needs to be completed in a defined space of time, and, secondly, the stakeholder associations and networks that are created throughout the project's progress are temporary; they will be created, and, after some time, disassociate or change. Furthermore, organizational narratives helped to analyze the interplay between all the project stakeholders, making the development of multiple narrative analyses therefore plausible. In the Sections 3 and 4, the outcome of the different analyses (i.e., stakeholder register, PI matrices, and stakeholder map) will firstly be presented as well as the general trends that were extracted from the narratives that were developed for this study.

\section{Results}

The marine turtle case study analyzed aimed at reducing bycatch rates by Spanish fishing fleets with a pilot study on the use of Turtle Excluding Devices (TEDs) in Calpe, on the coasts of Valencia. Twenty-one project stakeholders were interviewed. The only two stakeholders' groups that were not interviewed were the recreational fishermen and the civil society members.

From the interview information, a stakeholder register was developed as shown below (Figure 1). For each of the identified stakeholders, his/her identification details were recorded, together with their main expectations, and problems they may have experienced with respect to the project mission, as well potential solutions to these problems. 


\begin{tabular}{|c|c|c|c|c|c|c|c|c|c|}
\hline & \multirow[b]{2}{*}{ Position } & \multirow[b]{2}{*}{ Organization / Company } & \multirow[b]{2}{*}{ Location } & \multirow[b]{2}{*}{ Role in Project } & \multicolumn{3}{|c|}{ Stakeholder Classification } & \multirow{2}{*}{\begin{tabular}{|l|l} 
Problems experienced by these stakeholders \\
it & Problems experienced by these stakeholders
\end{tabular}} & \multirow{2}{*}{$\begin{array}{l}\text { Solutions to the se problems } \\
\text { Solutions to these problems }\end{array}$} \\
\hline & & & & & Main Expectations & $\begin{array}{l}\text { Internal } / \\
\text { External }\end{array}$ & $\begin{array}{l}\text { Defender I } \\
\text { Neutral I } \\
\text { Opponent }\end{array}$ & & \\
\hline 1 & $\begin{array}{c}\text { Director of Chelonia } \\
\text { Colombia }\end{array}$ & Chelonia & Madrid & Project member & $\begin{array}{l}\text { The successful execution and testing of } \\
\text { TED device, as well as the successful } \\
\text { completion of the project. }\end{array}$ & Internal & Defender & Dealing with the fishermen, getting onboard the ship. & $\begin{array}{l}\text { Greater degree of communication ensuring that thei role of the } \\
\text { fishermen is taken into account }\end{array}$ \\
\hline 2 & President of NGO & Chelonia & Madrid & Project lead & $\begin{array}{l}\text { The successful execution and testing of } \\
\text { TED device, as well as the successful } \\
\text { completion of the project. The ebtention of } \\
\text { funding to ensure the project's execution. }\end{array}$ & Internal & Defender & $\begin{array}{l}\text { Getting funding for the project, dealing with the } \\
\text { different stakeholders and ensuring project } \\
\text { completion }\end{array}$ & $\begin{array}{l}\text { Continue looking for funding in the different funding institutions } \\
\text { through grant applications, ensusuring communication between all } \\
\text { stakeholders through meetings and enanancing communication with } \\
\text { the fishermen (i.e. which is essential for project execution) }\end{array}$ \\
\hline 3 & Projects director & Chelonia & Galicia & Project management & $\begin{array}{l}\text { The successful execution and testing of } \\
\text { TED device, as well as the successful } \\
\text { completion of the project. }\end{array}$ & Internal & Defender & $\begin{array}{l}\text { Dealing with the fishermen (and ensuring project } \\
\text { execution) }\end{array}$ & $\begin{array}{l}\text { Greater degree of communication ensuring that thei role of the } \\
\text { fishermen is taken into account }\end{array}$ \\
\hline 4 & $\begin{array}{c}\text { Director of } \\
\text { Mediterranean } \\
\text { projects }\end{array}$ & Chelonia & Valencia & Project member & $\begin{array}{l}\text { The successful execution and testing of } \\
\text { TED device, as well as the successful } \\
\text { completion of the project. }\end{array}$ & Internal & Defender & Dealing with the fishermen & $\begin{array}{l}\text { Greater degree of communication ensuring that thei role of the } \\
\text { fishermen is taken into account }\end{array}$ \\
\hline 5 & Social Media & Chelonia & Valencia & Project member & $\begin{array}{l}\text { The successful execution and testing of } \\
\text { TED device, as well as the successful } \\
\text { completion of the project. }\end{array}$ & Internal & Defender & $\begin{array}{l}\text { Really no direct problems - Just ensuring that the } \\
\text { Social Media portray a positve image of Chelonia }\end{array}$ & No solution needed \\
\hline 6 & $\begin{array}{c}\text { Animal behaviour } \\
\text { professor }\end{array}$ & $\begin{array}{l}\text { Universidad Autonoma de } \\
\text { Madrid }\end{array}$ & Madrid & $\begin{array}{l}\text { Project collaborator } \\
\text { (Associated expert } \\
\text { researcher) }\end{array}$ & $\begin{array}{l}\text { The successful execution and testing of } \\
\text { TED device, as well as the successful } \\
\text { completion of the project. }\end{array}$ & Internal & Defender & Collaboration of the fishermen & $\begin{array}{l}\text { Greater degree of communication ensuring that thei role of the } \\
\text { fishermen is taken into account }\end{array}$ \\
\hline 7 & Professor & $\begin{array}{l}\text { Universidad Complutense de } \\
\text { Madrid }\end{array}$ & Madrid & $\begin{array}{l}\text { Project collaborat or } \\
\text { (Associated expert } \\
\text { researcher) }\end{array}$ & The successful execution of the project. & Internal & Defender & $\begin{array}{l}\text { No real problem with regards to this stakeholder as } \\
\text { there is no direct relationship between her and the } \\
\text { project }\end{array}$ & No solution needed \\
\hline 8 & Professor & Universidad de Valencia & Valencia & Project collaborat or & $\begin{array}{l}\text { The successful execution of the project as } \\
\text { well as the obtention of scientific data that } \\
\text { will only be possible with the collabor ation } \\
\text { of the fishermen, as well as the successful } \\
\text { execution of the project. }\end{array}$ & Internal & Defender & Collaboration of the fishermen to access data & $\begin{array}{l}\text { Greater degree of communication ensuring that thei role of the } \\
\text { fishermen is taken into account }\end{array}$ \\
\hline 9 & President of NGO & CEMMA & Galicia & External researcher & $\begin{array}{l}\text { No real interest or requirement of the } \\
\text { project as CEMA is an organiz ation that is } \\
\text { external to the project. Although they do } \\
\text { share a similar mission as regards to the } \\
\text { organiz ation, they really have no interest in } \\
\text { the project. }\end{array}$ & External & Defender & $\begin{array}{l}\text { No real problem with regards to this stakeholder as } \\
\text { there is no direct relationship between her and the } \\
\text { project }\end{array}$ & No solution needed \\
\hline 10 & President of NGO & Xaloc & Valencia & Project & $\begin{array}{l}\text { Xaloc's interest really is associated to the } \\
\text { successful carrying out of the project, for } \\
\text { the bycatch projectt to be successful and } \\
\text { for the sea turtle's to be saved. It is also in } \\
\text { Xaloc's interest to maintain a cordial } \\
\text { relationship with the fishermen. }\end{array}$ & Internal & Defender & Project funding and fishermen collaboration & $\begin{array}{l}\text { Greater degree of communication ensuring that thei role of the } \\
\text { fishermen is taken into account }\end{array}$ \\
\hline 11 & Scientific technician & Generalitat de Valencia & Valencia & Project collaborator & \begin{tabular}{|l|} 
The successful execution of the project \\
with the successful testing of the TEDs \\
with the collaboration of the fishermen, and \\
there resultingly saving of the marine \\
turtles.
\end{tabular} & Internal & Defender & $\begin{array}{l}\text { Stakeholder collaboration - Ensuring that this is a } \\
\text { realty and that there is collaboration from the } \\
\text { fishermen. }\end{array}$ & $\begin{array}{l}\text { Greater communcation and collaboration between all project } \\
\text { stakeholders and this will only be achieved through the increase and } \\
\text { improvement of communication between them. }\end{array}$ \\
\hline
\end{tabular}

Figure 1. Cont. 


\begin{tabular}{|c|c|c|c|c|c|c|c|c|c|}
\hline 12 & $\begin{array}{l}\text { President of fishing } \\
\text { association }\end{array}$ & Cofradia de Gandia & Gandia & Project collaborator & $\begin{array}{l}\text { Difficult stakeholder to deal with. In one } \\
\text { hand they do not wan their fishing } \\
\text { practices to be alterned, but they are } \\
\text { collaborating, and at the end want to save } \\
\text { sia turtles. However, the priority of course } \\
\text { is their fishing catches and they do not } \\
\text { want to be legally punished for bycatching } \\
\text { sea turtles. }\end{array}$ & Internal & Defender & $\begin{array}{l}\text { Representation - Their true protagonism being taken } \\
\text { into account and considered. }\end{array}$ & $\begin{array}{l}\text { Giving the fishing association a greater voice and greater } \\
\text { protagonism in the media and other means. Taking them more into } \\
\text { consideration tprotagonism in the different project activities and } \\
\text { recognising their work. }\end{array}$ \\
\hline 13 & Researcher & Universidad de Valencia & Valencia & Project collaborator & $\begin{array}{l}\text { The successful execution of the project as } \\
\text { well as the obtention of scientific datathat } \\
\text { will only be possible with the collaboration } \\
\text { of the fishermen, as well as the successful } \\
\text { execution of the project. }\end{array}$ & Internal & Defender & Collaboration of the fishermen to access data & $\begin{array}{l}\text { Greater degree of communication ensuring that thei role of the } \\
\text { fishermen is taken into account }\end{array}$ \\
\hline 14 & $\begin{array}{l}\text { Predoctoral } \\
\text { researcher }\end{array}$ & Universidad de Valencia & Valencia & $\begin{array}{l}\text { Project collaborator and } \\
\text { volunteer }\end{array}$ & $\begin{array}{l}\text { The successful execution of the project as } \\
\text { well as the obtention of scientific datathat } \\
\text { will only be possible with the collaboration } \\
\text { of the fishermen, sa well as the successful } \\
\text { execution of the project. }\end{array}$ & Internal & Defender & Collaboration of the fishermen to access data & $\begin{array}{l}\text { Greater degree of communication ensuring that thei role of the } \\
\text { fishermen is taken into account }\end{array}$ \\
\hline 15 & $\begin{array}{l}\text { Predoctoral } \\
\text { researcher }\end{array}$ & Universidad de Valencia & Valencia & $\begin{array}{l}\text { Project collaborator and } \\
\text { volunteer }\end{array}$ & $\begin{array}{l}\text { The successful execution of the project as } \\
\text { well as the obtention of scientific datathat } \\
\text { will only be possible with the collaboration } \\
\text { of the fishermen, sa well as the successful } \\
\text { execution of the project. }\end{array}$ & Internal & Defender & Collaboration of the fishermen to access data & $\begin{array}{l}\text { Greater degree of communication ensuring that thei role of the } \\
\text { fishermen is taken into account }\end{array}$ \\
\hline 16 & $\begin{array}{l}\text { Professor and } \\
\text { researcher }\end{array}$ & $\begin{array}{l}\text { Universidad Católica de } \\
\text { Valencia }\end{array}$ & Valencia & External researcher & $\begin{array}{l}\text { No direct relationship with the project but is } \\
\text { working alongside the perso that has } \\
\text { helped to deselop the TED Model that is } \\
\text { being tested in Valencia Evidentty Jose } \\
\text { Rafael wants the project to be successful } \\
\text { in order to save the marine turtles in the } \\
\text { area. }\end{array}$ & External & Defender & $\begin{array}{l}\text { No real problem with regards to this stakeholder as } \\
\text { there is no direct relationship between her and the } \\
\text { project }\end{array}$ & No solution needed \\
\hline 17 & Scientfic consultant & Secretaria General de Pesca & Madrid & $\begin{array}{l}\text { External project } \\
\text { supporter }\end{array}$ & $\begin{array}{l}\text { The successful execution of the project all } \\
\text { in favor of the conservation of the marine } \\
\text { turtles and protected marine areas. }\end{array}$ & External & Defender & $\begin{array}{l}\text { No real problem with regards to this stakeholder as } \\
\text { there is no direct relationship between her and the } \\
\text { project. Ensuring that the project is carried out in a } \\
\text { legal ethical manner. }\end{array}$ & $\begin{array}{l}\text { No real solution is needed here as the role of the S.G Pesca is more } \\
\text { legal than anything, although they may be of some help with regard to } \\
\text { getting the support of the fishermen. }\end{array}$ \\
\hline 18 & Volunteer & Chelonia & Huelva & Project volunteer & $\begin{array}{l}\text { The successful execution and testing of } \\
\text { TED device, as well as the successful } \\
\text { completion of the project. }\end{array}$ & Internal & Defender & Project funding and fishermen collaboration & $\begin{array}{l}\text { Greater degree of communication ensuring that thei role of the } \\
\text { fishermen is taken into account }\end{array}$ \\
\hline 19 & Professor & CEU & Valencia & Project volunteer & $\begin{array}{l}\text { The successful execution and testing of } \\
\text { TED device, as well as the successful } \\
\text { completion of the project. }\end{array}$ & $\begin{array}{c}\text { InternavExt } \\
\text { ernal }\end{array}$ & Defender & $\begin{array}{l}\text { No real problem with regards to this stakeholder as } \\
\text { there is no direct relationship between her and the } \\
\text { project }\end{array}$ & No solution needed \\
\hline 20 & $\begin{array}{l}\text { Entrepreneur and } \\
\text { professor }\end{array}$ & EAE Business School & Madrid & External & $\begin{array}{l}\text { No real interest in the project but in favour } \\
\text { of marine turtle conservation. }\end{array}$ & External & Defender & $\begin{array}{l}\text { No real problem with regards to this stakeholder as } \\
\text { there is no direct relationship between her and the } \\
\text { project }\end{array}$ & No solution needed \\
\hline 21 & $\begin{array}{l}\text { Representative of } \\
\text { ICUN (Specify } \\
\text { specific role) }\end{array}$ & IUCN & Malaga & External & $\begin{array}{l}\text { Successful project execution to benefit the } \\
\text { marine turtles }\end{array}$ & External & Defender & $\begin{array}{l}\text { No real problem as regards to the project. Is a } \\
\text { supporter of the all project activities. The IUCN } \\
\text { basically establishes the conservation status of the } \\
\text { marine turtles. }\end{array}$ & No solution needed \\
\hline
\end{tabular}

Figure 1. Stakeholder register of marine turtle bycatch project. 
The stakeholders listed in Figure 1 were also categorized as being internal or external to the project, as well as whether they defended or opposed the project. Furthermore, the information compiled in the stakeholder register was further analyzed via the development of a stakeholder map for the project, where, as shown below in Figure 2, project defenders were characterized by stars and project opponents by hexagons. Although the trends extracted from the stakeholder map are further described in the Section 4 below, it is possible to observe that most of the interviewed stakeholder groups supported the project mission. As will be later described, the fishermen were probably the stakeholder group that was more reticent with regard to the project. The problem that this target group had, with regard to the project mission, was that they felt as though they were blamed for marine turtle deaths, as well as for the deaths of many target fish species, and overall weren't really being given proper consideration in the matter. Finally, the civil society and the recreational fishermen were characterized graphically by a gray star (i.e., as they were not interviewed), as it was not possible to determine whether they defended or opposed the project since no member of either group was interviewed.

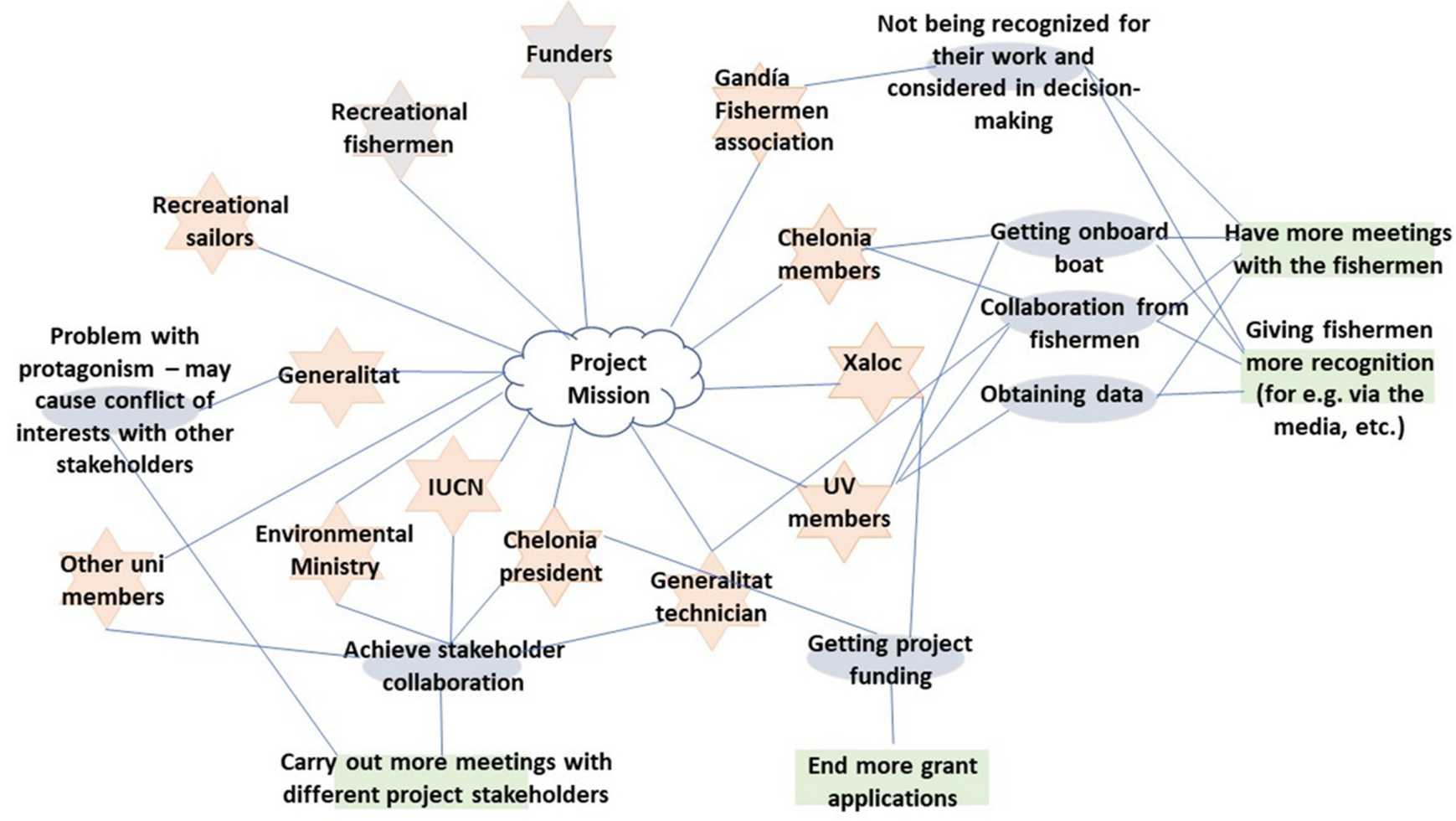

Figure 2. Stakeholder map of the marine turtle bycatch project.

The perspectives of the different stakeholder groups interviewed were compiled so that trends could be extrapolated on how the different groups evaluated the respective power and interest levels of the project stakeholder groups. An example of the latter with the perspective of the regional government environmental representative is shown below in Figure 3. 


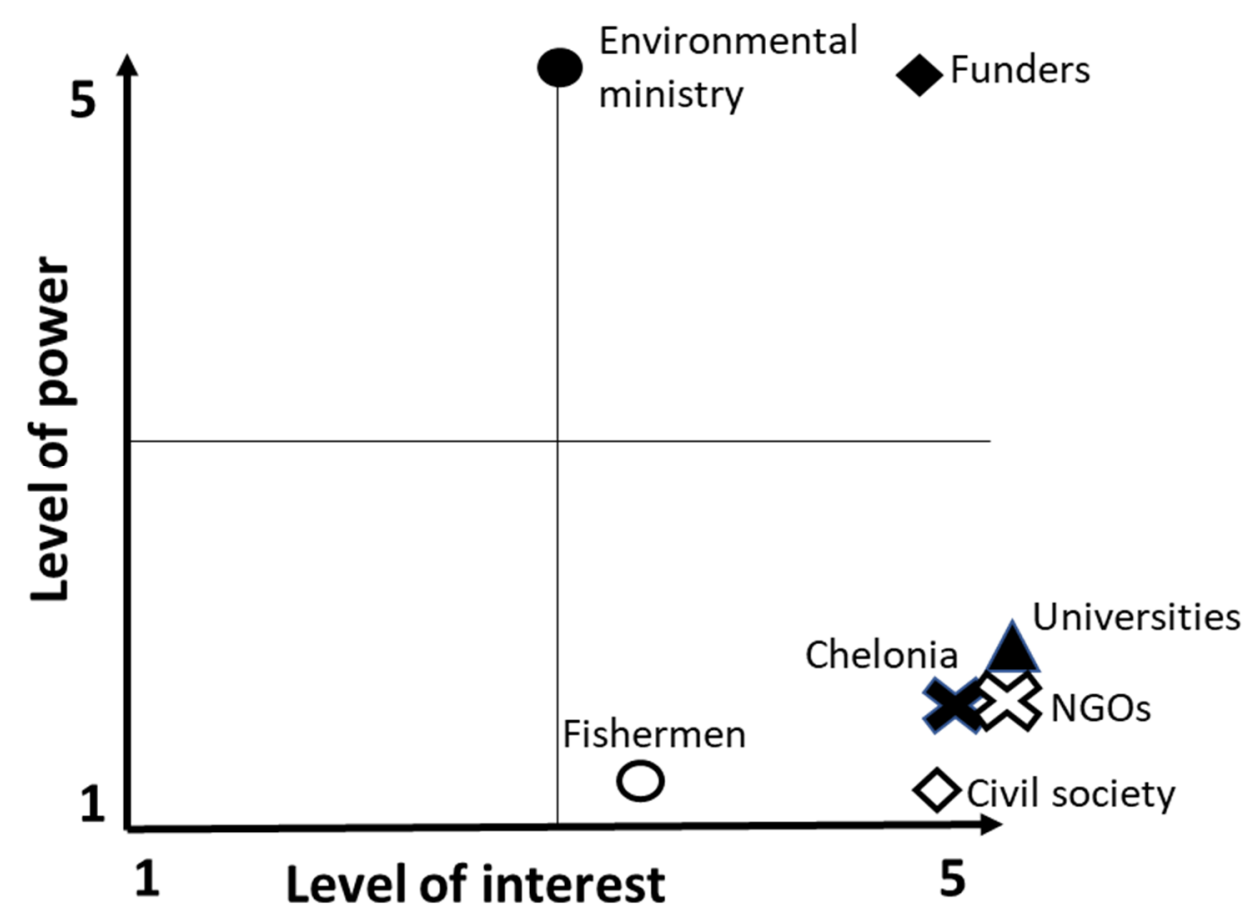

Figure 3. Power-Interest matrix generated from the interview with the regional government representative.

The only perspective that was not analyzed in the PI matrices was that of the Gandía fishermen's association, as its president did not consider that he had the knowledge to carry out the exercise. Therefore, the groups whose perspectives are represented are:

- Chelonia members

- The NGOs

- The universities

- The regional government

- The national government

- The University of Valencia researchers

In the matrices, as shown in the NGO example above (Figure 3), each stakeholder group was represented with a different shaped figure such as the fishermen with a white circle or the environmental ministry with a black circle. Table 1.

The general trends that were extracted from these PI matrices are listed below in 
Table 1. Power-Interest matrices of perspectives of different stakeholders.

- Governmental authorities were considered to be rather powerful; however, the level of interest in the project varied.

- The scientists had considerable interest in the project but medium power.

- The funding bodies of the project were also found to be powerful but had medium interest.

- The level of the civil society was found to have low power and variable interest.

- The fishermen had varying levels of power and overall low interest levels.

- $\quad$ NGOs were considered to have high interest levels but medium power levels. Chelonia members included themselves here as NGO members.
- The UV members saw themselves as having high interest but low levels of power in the project.

- Chelonia was considered to have medium-high levels of both power and interest (with levels of over 3 out of 5 in both categories)

- $\quad$ Then, NGOs were perceived as having considerable interest but as not being too powerful.

- The perspectives regarding the fishermen varied considerably. One scientist considered that the fishermen had no power, while another said they had considerable power levels.

- The power levels of the governmental authorities were considered to be elevated, while the interest levels were found to vary.

- The positioning of the civil society members was also found to vary considerably with no general observable trend.
- The funders were found to be the most important stakeholders with high power and high interest.

- The NGOs, universities, and Chelonia were positioned the same with high interest and low power.

- The regional government rated itself as having high power and medium interest.

- The fishermen had a more than average interest but little power.

- The civil society was considered to have relatively high interest and no power.

\section{Governmental Authority}

- Chelonia and the universities were positioned the same. They were found to have great interest in the project and considerable power.

- The other NGOs were also perceived to have high interest in the project but had medium power.

- The civil society was found to have medium power and interest.

- The fishermen (fishermen associations) were considered to have both high power and interest.

- The project funders were perceived to have relatively high power and interest.
- The fishermen and fishing associations (Cofradía) had great interest in the project but no power.

- The turtles and the fish had both relatively high interest and power.

- The universities had considerable interest and little power.

- Chelonia and the NGOs were positioned the same with medium interest and relatively high power.
Other Universities

- The other NGOs, although they were considered to have quite a lot of interest, were found to have limited power.

- The interest of the project holding organization Chelonia was perceived to be high; however, the power varied to being low on one occasion and high in another.

- The position of the fishermen also varied to one having no interest and relatively high power, to another having medium interest and very low power.

- Only one university member commented on the position of the governmental figures, which were considered to be of medium power and relatively low interest.

- The universities had high interest and medium power. 


\section{Discussion}

The analyzed marine turtle case study aimed at reducing bycatch rates by Spanish fishing fleets through a pilot study on the use of Turtle Excluding Devices (TEDs) in Calpe on the Levante Coast. The target species of the project is the loggerhead turtle as it is the species that is the most prevalent in the geographical region of the Mediterranean. What is singular about this bycatch project is the use of innovation and technology to reduce sea turtle bycatch, using TED (Turtle Excluder Devices). The idea was to use these TED to reduce levels of bycatch by the area's fishermen.

A pilot project in Calpe was thus led by the NGO Chelonia in collaboration with a variety of different stakeholders and aimed at reducing bycatch rates through the installation of TED in local fishing boats, as will be described later. The idea is, if the study is successful, to implement TEDs in all boats of the Valencian fishing fleet.

The Valencian marine turtle project is an excellent case study to work with to examine the challenges of working in a multi-actor governance context to achieve the project's mission, which is to reduce marine turtle bycatch rates. In this sense, the specific project's objective may be linked to Target 14.2 of SDG 14, which is linked to the sustainable management and protection of marine and coastal ecosystems.

In this respect, over the years, Chelonia has worked with several different stakeholders, with whom, over time, it has come to establish a trustworthy relationship. Most stakeholders according to stakeholder register (Table 1) and map (Figure 1-represented by stars) were found to engage cooperatively throughout the project's execution, besides sharing the same project objective, which is to reduce bycatch levels in the waters of the Levante Coast. There was, however, one stakeholder that was the most challenging to deal with, namely the fishermen themselves. However, with the help of the Valencian Government (i.e., Generalitat Valenciana), the fishermen have come over time to support the bycatch project (i.e., and the work of the scientists of both NGOs and universities).

In the year 2020, the United Nations developed the 2030 Agenda Partnership Accelerator, which is a collaborative approach associated with SDG 17 to "significantly help to accelerate and scale up effective partnerships in support of the 2030 Agenda for Sustainable Development [16]. This initiative highlights the importance of multi-stakeholder partnerships and describes it as "An ongoing collaborative relationship among organisations from different stakeholder types aligning their interests around a common vision, combining their complementary resources and competencies and sharing risk, to maximise value creation towards the Sustainable Development Goals and deliver benefit to each of the partners" [16].

It is also important to note that nowadays a requirement to obtain research project funding is for the project to adopt a multi-stakeholder approach. Therefore, the execution of SDG 17 is often a prerequisite to fund marine conservation projects. "Challenges are that there are more and more people and maintaining a network of contacts is very important. Collaboration is very necessary as, for some project grant calls, NGOs may not apply without the support of other kinds of organizations and vice versa" (In a conversation with UV researcher, February 2019).

In the interview, respondents were asked how they viewed Nature. This was a very important question, as a common vision of what Nature entails will determine whether stakeholders are aligned or not with the project mission, which is the conservation of the marine turtles and the reduction of marine turtle bycatch. This common perspective of Nature seemed to engender and set the scene for collaboration between the different project stakeholders. Most interviewees considered that Nature encompassed both human and nonhuman elements and that these had to work together and be in equilibrium. The attitudes became more positive over time. The only stakeholders that were not represented in our study were the recreational fishermen and the civil society, as it was not possible to interview any member of these two stakeholder groups. Furthermore, there were also difficulties contacting the commercial fishermen. It was only possible to interview the president of the Gandía fishermen's association, even though all fishing associations from 
the Levante Coast were contacted. Their lack of participation in this study could therefore perhaps be perceived as there being a lack of trust from their end.

All of the members of the project holding organization Chelonia were found to be project supporters and their perspective was very much aligned with that of the members of the other NGOs supporting the project like Xaloc, and that of the scientific researchers from the University of Valencia (UV). With respect to the project objective, three problems were shared by these stakeholder groups (Figure 1); (i) the problem of getting onto the fishing vessels themselves, (ii) gaining the collaboration of the fishermen, and (iii) obtaining the necessary scientific data to be able to continue with their research. At the end of the day, this all boils down to the first point of getting the Chelonia and Xaloc members, as well as the scientists onboard the commercial fishing boats. One of the UV scientists noted in February 2019, "I think that the most important would be the fishing part. Everything that is related to fishing, really everything, depends on the fishermen, on whether they want or not to collaborate." Without the fishermen, the scientists would not be able to get their data, nor complement the latter with qualitative data regarding the fishermen's experience at sea.

The fishermen were probably the most challenging stakeholders to deal with, especially at the beginning of the project, both for the universities and the NGOs. The fishing sector, however, is a circle that is rather "closed" and difficult to deal with. From the scientific perspective, it is rather difficult and complex to develop a long-standing relationship with them and developing such a relationship takes considerable time. It must be noted that the fishermen were probably the most sensitive stakeholders with regards to the project's execution. According to the fishermen, scientists were distanced from the reality of the fishermen working for a living and just came aboard to obtain their data. Furthermore, the fishermen are also reticent about implementing changes in their way of working (i.e., that is to implement the TED on their boats). Part of the reason for the latter is that often the fishermen are blamed for many of the things that happen out at sea, such as marine conservation problems, the reduction of certain fishing target species, or the bycatching of marine turtles and other marine mammals. "There are a multitude of factors that have an impact on fishing. Not the fishermen themselves but factors inherent in fishing itself as an activity ... No, I say again that we have reduced our fishing by $38 \%$ so if it was because of us, then the sea would be full of fish by now" (In a conversation with the Gandía fishermen's association president, February 2019).

Empathy was therefore necessary from the part of the scientists when dealing with the fishermen. They needed to understand that, if the fishermen decide to collaborate and participate in the project, the decision will probably affect the quantities of fish that they catch, and consequently affect their livelihood. Fishing is obviously a way of life for the fishermen (i.e., not a recreational activity), and the scientists needed to respect this. Therefore, empathy was the key to getting them on board with the project and the scientists presented to the fishermen the advantages and potential benefits that the project could bring to them. The scientists at Chelonia and the University of Valencia needed, therefore, to understand, show empathy, and respect the fishermen. Furthermore, the project is not just quantitative but also involves the obtention of qualitative data. This was a problem for the project biologists as they weren't used to analyzing this type of data and had to bring social scientists into the project team. The results obtained from the testing of the TEDs also needed to be communicated to the fishermen to discuss with them and obtain their input with regard to the evaluation of the best conditions to install the TEDs. Furthermore, the scientists needed to add value to the work of the fishermen and reinforce a positive message with regard to the potential result of the project, and how the latter would benefit the fishermen. Such careful actions by the scientists will contribute to ensuring the collaboration of the fishermen in pursuit of the project goals.

Over time, fishermen have come to feel that their position has never really been properly considered. For example, when drawing up the conservation regulations for the protection of the marine turtles at a national or European level, authorities have usually 
based their reasoning and decision making on rigid scientific experimentation and observation. One of the trusted information sources is the International Union for the Conservation of Nature that derives its knowledge from a compendium of scientific sources of experts that specialize in the observation and conservation of marine turtles. However, could the fishermen's own hands-on experience and knowledge be given more protagonism?

The president of the fishermen's association interviewed said that the fishermen really had no interest in catching sea turtles or in having dead turtles in their nets. They therefore did not want the problem to continue and did not want to get into any legal conflict with the Spanish authorities due to turtle bycatching. Apart from the legal problems, the fishermen did not want the bycatching of sea turtles to give them a bad image among the civil society. Therefore, one of the fishermen's main worries was the cleaning up of their image. "The positive aspect is sometimes cleaning up one's image. It goes beyond saving the lives of many turtles, cleaning up the image of the fishermen is important" (President of Gandía fishermen's association).

It must also be noted that the Gandía Fishermen association has been involved in a few conservation initiatives, some of these aimed at giving a positive image to the fishermen. One of these actions is the recovery of bycaught turtles. When one is found, the fishermen call 112, which is the general number for the emergency services, which, when contacted, will come and take the turtles. In fact, it is the association that has recovered to date the greatest number of turtles. Furthermore, a yearly contest has been organized to motivate fishermen in recovering marine turtles and the winner is given a weekend in a five-star hotel. Finally, the Gandía association has also been involved in several European projects; some of them associated with the global marine plastics problem, which is nowadays so much in the media.

Over time, during the project and with the help of the Valencian Government (i.e., Generalitat Valenciana), the fishermen have come to support the bycatch project. The environmental representative from the Generalitat was key in promoting the collaboration between the NGO/Scientists and the fishermen. The environmental representative, through his charisma and empathy, has been able to get stakeholder collaboration from all parties. In the marine turtle project, he facilitated access for Chelonia and the scientists to the fishermen and fishermen's associations. Over time, he was able to demonstrate to the fishermen that Chelonia was a trustworthy organization. At present, he is considered to be "a fellow fisherman" by the Levante Coast fishermen, and it is not strange to maybe see him in a bar in Gandía having a beer with them. "If they see you as a government representative, all they will convey to you are their complaints and they will tell you that the government is not helping them, and that the local government does not allow them to do this and that" (In a conversation with Generalitat environmental representative, February 2019). Juan's active participation with the fishermen over the past 26 years has brought the result of ensuring the fishermen's participation in the project, and has brought many parties together and over time created a strong multidisciplinary collaboration between the different project stakeholders; universities, NGOs, and local governments. He has played an especially important role in getting the fishermen on board with the different projects that work towards marine conservation.

Therefore, the scientists needed to understand that empathy and respect were needed when dealing with the fishermen. The scientists needed to understand that, if the fishermen decide to collaborate and participate in the project, that decision will probably affect the quantities of fish that they catch, and consequently affect their livelihoods. Moreover, it should also be taken into consideration that fishing is a socioeconomic activity that needs to exist and be sustained over time. There are several reasons for this; firstly, a large part of the society depends on seafood and fish as part of their diet, and, secondly, there are hundreds of thousands of fishermen and other stakeholders who depend on fish for their livelihoods.

Furthermore, the scientists were surprised that this work would have unexpected advantages. Being usually guided by scientific rigor, the scientists found out that they could compile additional first-hand information (i.e., qualitative data) from the sea, such 
as additional elements to observe when a turtle is bycaught or other novel events of potential scientific interest that would have remained unknown to the scientists had they simply stayed in their labs or office, and thus they were able to obtain extra data. The results obtained from the testing of the TEDs will also be communicated to the fishermen to discuss with them and obtain their input with regard to the evaluation of the best conditions to install the TEDs (i.e., any modifications of the latter to be made throughout the experimentation period). This was a problem for the project biologists as they weren't used to analyzing this type of data and had to bring social scientists into the project team.

The scientists therefore needed to be more empathetic and develop a more cordial relationship if they wanted to get onboard the fishing boats and get their data. To do this, they learned through time that it is essential to provide the fishermen with their share of protagonism, such as mentioning them in newspaper articles when referring to the project and in the media whenever they were interviewed and asked about their research. The scientists therefore needed to recognize and acknowledge the importance of the fishermen's participation in the project in order to dissipate the high levels of distrust that the fishermen initially had of the scientists. Additionally, the scientists also needed to highlight the multiple benefits that the installation of TEDs on the fishing boats, which included the potential for catching fish of better quality thanks to the project (i.e., in the sense that the target species would not get squashed by the bycatching of marine turtles and large marine mammals). Such careful actions by the scientists will therefore contribute to ensuring the collaboration of the fishermen in pursuit of the project goals.

In this multi-actor governance context, it is interesting to note the role of the international and national authorities. In Spain, the panorama is different from that of other countries in Europe, in the sense that these measures at the state level need to be applied by the environmental ministry (i.e., presently called the Ministerio para la Transición Ecológica) and also at the autonomous community level. Spain is divided into autonomous communities ("comunidades autónomas"), which are in themselves composed of provinces. Overall, there are 17 autonomous communities in Spain and 52 provinces. A great risk to consider may be a change in political control, whether it is to the right or to the left wing, as this may affect the continuation of the funding of conservation projects and therefore the viability of the execution of the subsequent necessary conservation measures and their potential funding. This is very much applicable to the bycatch project, for example, as the project was partially funded by the Biodiversity Foundation (Fundación Biodiversidad), which comes under the Spanish environmental ministry. However, as noted by the project holding organization president, "We are working with protected species under Spanish regulations, international European Community agreements, the IUCN, protected by CITES or regulated by CITES international trade agreements. In other words, the situation of marine turtles encompasses a whole host of management and protection measures that are global, because they are not from specific countries or regions" (In a conversation with the Chelonia president, February 2019). Therefore, it is highly unlikely that the Ministry will seek to alter the sea turtles' conservation status established by the IUCN, nor that a political change will affect the project's continuation.

A multi-actor governance perspective is necessary to be undertaken in order to ensure the proper execution of the marine turtle bycatch conservation project. This is especially so considering the actual nature of the project, which is not limited to the geographical boundaries of a country. Therefore, what happens in the Mediterranean Sea, may also affect what happens in the waters of the other side of the world in the Indian Ocean for examples. Furthermore, often, conservation project grant funding organizations such as the IUCN or the European Commission require, in their grant application for different organizational types (i.e., and often from different countries), to be represented. Often, if the latter requirement is not fulfilled, the grant will not be awarded to the organization. 


\section{Conclusions}

The United Nations developed in 2020 the "SDG Partnership Book", which is described as a "A practical guide to building high impact multi-stakeholder partnerships for the Sustainable Development Goals." The Partnership Accelerator "aims to develop the partnership-enabling ecosystem (see above) which can support the engagement of business as a partner in sustainable development and accelerate the number and effectiveness of partnerships towards delivering the 2030 Agenda." According to this document, effective partnering can be executed successfully through: (i) Self-awareness, (ii) Contextual awareness, and (iii) Awareness of the complex interplay between oneself and one's context. For this research, a neutral stance needed to be undertaken from the researcher's perspective.

The marine turtle conservation project in Valencia (Spain) is a case study worth studying to analyze the viability of SDG 17 in achieving specifically Target 14.2 of SDG 14, which aims to "by 2020, sustainably manage and protect marine and coastal ecosystems to avoid significant adverse impacts, including by strengthening their resilience, and take action for their restoration in order to achieve healthy and productive oceans." To achieve this project, the partnering of a number of very different stakeholders was necessary, including public officials with environmental responsibilities, fishermen's associations, NGOs, and university professors. From the different analyses that were performed in this study, it did seem that most of the stakeholders seemed to support the project. The most difficult stakeholder to deal with were the fishermen (i.e., represented in the study by Gandía fishermen's association).

The mission of this project was to reduce marine turtle bycatch through the installation of Turtle Excluding Devices (TEDs) in the fishing boats of the commercial fishermen. Initially, there was distrust among the fishermen of the motives of the scientists; however, over time, this position changed, and the fishermen allowed the scientists to accompany them onboard and test the TED devices. This change in attitude was due to a couple of different factors:

- Firstly, there was the Valencian regional government representative who played the role of a mediator between the scientists and the fishermen. Without his aid, perhaps the association between those two stakeholder groups may have not been possible.

- Secondly, what has further enabled this change of attitude is the fact that all project stakeholders seemed to share a common viewpoint with regard to the element of Nature present in the project. This was a very important question, as a common vision of what Nature entails will determine whether stakeholders are aligned or not with the project mission. This common perspective of Nature seemed to engender and set the scene for collaboration between the different project stakeholders. Most interviewees considered that Nature encompassed both human and nonhuman elements and that these had to work together and be in equilibrium.

The fishermen, for their part, did not want to be blamed for the bycatch of marine turtles and other marine mammals, as well as for the reduction in fish target populations. Additionally, they felt that they were not really being properly considered with regard to legal decisions concerning marine conservation (i.e., for both ecosystems and species). Finally, the implementation of TEDs in the fishing boats may have potentially also altered the fishermen's fish captures, and consequently their income. This last point may also have made the fishermen reluctant to support the bycatch marine turtle conservation project initially.

The study was used to demonstrate how a multi-actor governance context can be effective in attaining a project's SDG 17. Partnership for the Goals could be potentially used to promote SDG 14, "Life under water," whose aim is to "conserve and sustainably use the oceans, seas and marine resources" [9]. Although this case study is specifically applicable to a marine conservation context, it may be extrapolated and applied to any other SDG context.

It is sometimes difficult to define stakeholders in the SDG context. In this respect, SDG 17, which encompasses a multi-actor governance approach, helps to: (1) ensure stakeholder 
participation, (2) identify the barriers that could hinder this engagement, and (3) develop a multi-actor network. All the latter will enable a better prioritization of the issues to be dealt with in the project, as well as the development of more efficient strategies on how to integrate and better engage the different stakeholders in the project.

Authors such as Susskind and Cruikshank have pointed out that negotiated agreements tend to produce fairer, more efficient, and stable solutions, compared to those decisions that have been taken unilaterally (i.e., by national governments). This demonstrates that multi-actor governance approaches are much better than traditional ones. Project stakeholders should therefore be involved at various levels of governance from local to regional and international levels. At each of these levels, agreements need to be developed and agreed upon to ensure that the multi-actor governance context is maintained.

Most public collective governance initiatives are anchored in facilitating transparency, accountability, and participation (of stakeholders). These three critical ingredients are essential to strengthen governance at all levels. In this respect, SDG 17 is useful in promoting global alliances and multi-actor governance in a world that is totally interconnected between national and local governments, companies, civil society, and academia. The Valencian marine turtle conservation project that was analyzed in this article is a very good example of this. Marine conservation has no geographical boundaries, and a multi-actor type governance involving a multitude of stakeholders is essential to ensure the successful achievement of conservation projects worldwide.

Author Contributions: The research for this article was carried out by the corresponding author E.B. and supported by C.d.P.-H. from the Rey Juan Carlos University of Madrid. All authors have read and agreed to the published version of the manuscript.

Funding: This research received no external funding.

Informed Consent Statement: Informed consent was obtained from all subjects involved in the study.

Data Availability Statement: The data used for this study were gathered for this specific study.

Acknowledgments: We would firstly like to thank the support that we have obtained from the organization Chelonia, as, thanks to its president and team, we have been able to carry out all of the empirical work for this research. We also extend a big thank you to all of the interviewees that participated in this research. Furthermore, we would like to thank the EAE Business School for supporting our research.

Conflicts of Interest: The authors declare no conflict of interest.

\section{References}

1. Erling, H.; Linnerud, K.; Banister, D. Sustainable Development: Our Common Future revisited. Glob. Environ. Chang. 2014, 26, 130-139.

2. Gupta, J.; Vegelin, C. Sustainable development goals and inclusive development. Int. Dev. Agreem. 2016, 16, 433-448. [CrossRef]

3. Commission on Global Governance. Our Global Neighbourhood: The Report of the Commission on Global Governance; Oxford University Press: Oxford, UK, 1995; p. 2.

4. Newell, P.; Pattberg, P.; Schroeder, H. Multiactor governance and the environment. Annu. Rev. Environ. Res. 2012, 37, 365-387. [CrossRef]

5. Newell, P. Climate for Change: Non-State Actors and the Global Politics of the Greenhouse; Cambridge University Press: Cambridge, UK, 2000.

6. Betsill, M.; Correll, E. NGO Diplomacy: The Influence of Nongovernmental Organizations in International Environmental Negotiations; MIT Press: Cambridge, MA, USA, 2008.

7. United Nations. 17 Goals to Transform our World. Available online: https://www.un.org/sustainabledevelopment/ (accessed on 1 March 2021).

8. United Nations and the Partnering Initiative. Partnership Platforms for the Sustainable Development Goals; United Nations: New York, NY, USA, 2020.

9. United Nations. Goal 14: Conserve and Sustainably Use the Oceans, Seas and Marine Resources. Available online: https: //www.un.org/sustainabledevelopment/oceans/ (accessed on 1 March 2021).

10. IUCN. About International Union for Conservation of Nature. Available online: https://www.iucn.org/about (accessed on 1 March 2021). 
11. Winch, G.; Bonke, S. Project Stakeholder Mapping: Analyzing the Interests of Project Stakeholders. In The Frontiers of Project Management; Cleland, D.I., Pinto, J.K., Eds.; Project Management Institute: Newtown Square, PA, USA, 2002.

12. Callon, M. Some elements of a sociology translation: Domestication of the scallops and fishermen of St. Brieuc Bay. In Power, Action and Belief: A New Sociology of Knowledge; Law, J., Ed.; Routledge \& Kegan Paul: London, UK, 1986; pp. $277-303$.

13. Callon, M.; Latour, B. Unscrewing the big Levathan: How actors macrostructure reality and how sociologists help them to do so. In Advances in Social Theory and Methodology: Towards an Integration of Micro- and Macro- Sociologies; Knorr-Cetina, K., Cicourel, V., Eds.; Routledge \& Kegan Paul: Boston, MA, USA, 1981.

14. Missioner, S.; Loufrani-Fedida, S. Stakeholder analysis and engagement in projects: From stakeholder relational perspective to stakeholder relational ontology. Int. J. Proj. Manag. 2014, 32, 1108-1122. [CrossRef]

15. Vaara, E.; Sonenshein, S.; Boje, D. Narratives as Sources of Stability and Change in Organizations. Acad. Manag. Ann. 2016, 10, 495-560. [CrossRef]

16. United Nations; UNDESA. The SDG Partnership Guidebook: A Practical Guide to Building High Impact Multi-Stakeholder Partnerships for the Sustainable Development Goals; United Nations: New York, NY, USA, 2020. 